\title{
Microarray-Based Transcriptome Analysis of Recombinant Pichia Pastoris Strains Overexpressing Alpha-Amylase and Interleukin-2
}

\author{
Cam Thuy Duong, Thi Thu Hong Le, Thanh Ngoc Nguyen, Hong Thanh Nguyen, Thi Lan Anh Le, and \\ Nam Hai Truong
}

\begin{abstract}
DNA microarray has been a useful tool for global-scale transcriptome analysis. To study the cellular response to expression of recombinant proteins, we compared the transcriptional profiles of recombinant Pichia pastoris strains overexpressing amylase and interleukin-2 versus that of the control strain at different cellular states. The microarray analysis was carried out via the use of Yeast_2 array specific for Saccharomyces cerevisiae and Schizosaccharomyces pombe. The transcirptome analysis of each studied strain at logarithmic growth phase and stationary growth phase showed hundreds of significant differences. In contrast, in comparison of studied strains at the same time points, the numbers of gene which are differentially expressed is rather low. Interestingly, the expression of heterologous alpha-factor secretion signal in the strains overexpressing amylase and interleukin-2 was up-regulated by more than 15 times and 140 times at the exponential and stationary phase, respectively. The results also provide evidence about the false positive result in microarray data when using non-specific array.
\end{abstract}

Index Terms-Pichia pastoris, microarray, transcriptome, IL-2, $\alpha$-amylase

\section{INTRODUCTION}

The methylotrophic yeast Pichia pastoris is a suitable host for production of heterologous proteins [1], [2]. It is observed that some proteins are produced at high level whereas other proteins are secreted at low yield in this system. The expression of foreign proteins can trigger the host cell response and then make changes to the process of cell metabolism. These changes can lead to instability of the foreign gene, disruption of ribosome structure, inhibition of the growth or even the destroy of the cell. Thus, these may adversely affect the ability to generate recombinant protein. To solve this problem, a number of studies have attempted to improve the recombinant proteins expression by the alteration of the genetic codes [3], co-expression along with a chaperone or with other proteins [4], [5], optimization of culture conditions [6], [7] and modification of genetics of the host strain [8]. The information established from the approaches can also be applied to increase production of other recombinant proteins, but not all cases are successful as

Manuscript received on November 7, 2011; revised November 22, 2011 This work was financially supported under the Fund of National Key Laboratory of Gene Technology, Institute of Biotechnology (IBT), Vietnam Academy for Science and Technology (VAST).

Authors are with IBT, VAST, 18 Hoang Quoc Viet, Hanoi, Vietnam (Corresponding Author: Prof. Dr. N.H. Truong, Tel/Fax: 0084-4-3756 2790; e-mail: tnhai@ibt.ac.vn). basic knowledge of the yeast physiology and molecular genetics is still not sufficient for a comprehensive assessment of the heterologous gene expression.

DNA microarray is a powerful tool to study transcriptional expression at the global scale. In P.pastoris, microarray-based transcriptome analysis has been applied to elucidate the regulation of host cell during protein production. Most of the researches have mainly focused on analyzing different transcriptional expression patterns of the recombinant strain under stress conditions such as temperature, oxygen, etc for understanding the molecular mechanism of the heterologous gene expression [9]-[11]. The result of the transcriptome analysis can be used for enhancing secretion of heterologous protein in the yeast [12].

Whole genome sequences of two P. pastoris strains GS115 and DSMZ 70382 have been published [13]-[15]. Nevertheless, the array specific for $P$. pastoris has not yet been available. Due to that fact, most of global transcriptional studies in P. pastoris so far have been conducted via the use of arrays from closely related yeast species e.g. S. cerevisiae.

In our study, the transcriptomes of the recombinant P. pastoris strains producing alpha-amylase, interleukin-2 were investigated in methanol induced cultures at different time points. The main aim of this work is to monitor the transcriptional patterns of the recombinant $P$. pastoris strains harboring different genes to obtain valuable information for understanding the gene expression and then propose a suitable way to improve the recombinant protein expression. The transcriptional profiles of the studied strains were analyzed via the use of Yeast_2 microarray specific for Saccharomyces cerevisiae and Schizosaccharomyces pombe.

\section{MATERIALS AND METHODS}

\section{A. Strains Used in the Study}

Strains used in this study include two recombinant P.pastoris strains overexpressing $\alpha$-amylase and interleukin-2 and their relevant control strain. For simplicity, the strains were respectively denoted as Amy, IL-2 and control strains. The control strain was generated via the integration of pPIC9 vector into the host P.pastoris SMD1168 genome at his 4 locus. Accordingly, the integration of pPIC9 vector harbouring recombinant gene (either $A M Y$ or $I L-2)$ into the SMD1168 genome results in the generation of the recombinant yeast strains. The recombinant gene encoding $\alpha$-amylase was derived from S. fibuligera while the recombinant $I L-2$ was originated from human. 
A

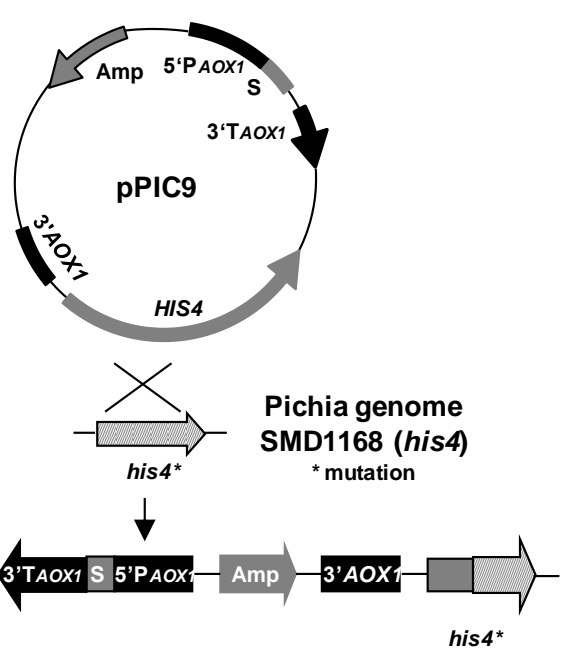

B

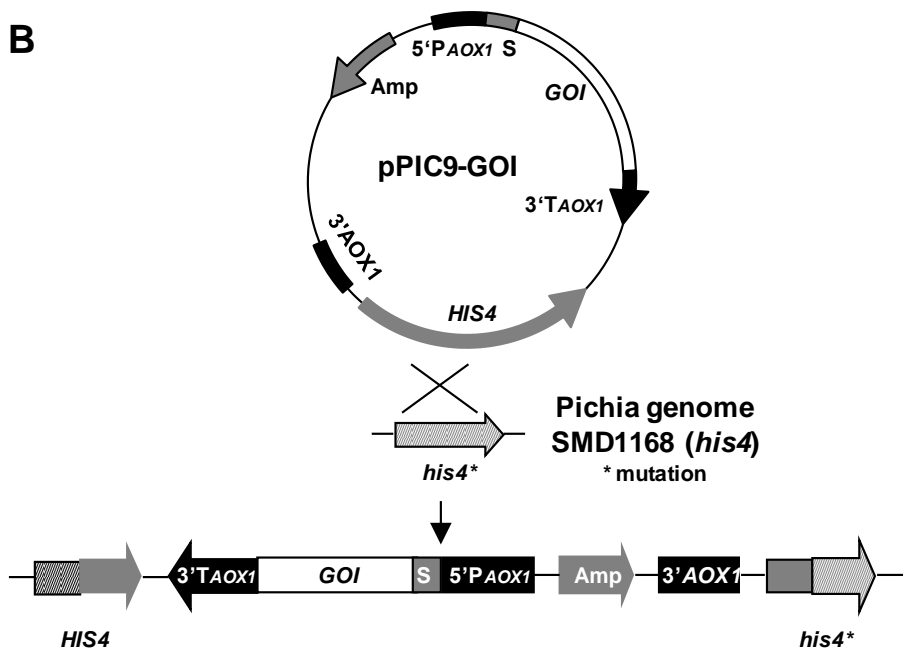

Fig. 1. Strategy employed for generation of studied Pichia pastoris strains. A: control strain; B: Strains overexpressing recombinant proteins, i.e. amylase (AMY) or interleukin-2 (IL-2). 5' $\mathrm{P}_{\mathrm{AOX1}}$ : 5' AOX1 promoter fragment; S: $\alpha$-factor secretion signal (MF(ALPHA1)); 3' $\mathrm{T}_{A O X I}$ : 3'AOX1 terminator; 3'AOX1: 3' AOX1 fragment; Amp: Ampiciline resistance gene; GOI: gene of interest

\section{B. Fermentations}

Yeast cells from MD agar plates were pre-cultured into 100 $\mathrm{ml}$ Erlenmeyer flasks containing $20 \mathrm{ml}$ of BMGY. The precultures were incubated at $28{ }^{\circ} \mathrm{C}$ on a rotary shaker $(250 \mathrm{rpm})$ overnight until optical cell densities $\left(\mathrm{OD}_{600}\right)$ of 6 were reached. The precultures were inoculated into 1 litre Erlenmeyer flask containing $300 \mathrm{ml}$ BMGY [16] at $\mathrm{OD}_{600}$ of 0.1 for fermentation with shaking at $250 \mathrm{rpm}$ at $28^{\circ} \mathrm{C}$. When the cell optical density $\left(\mathrm{OD}_{600}\right)$ of fermentation reached to the values from 15 to 16 , the fermentation cultures were induced with $\mathrm{MeOH}$ at the final concentration of $1 \%$. After that, the cultures were induced with $\mathrm{MeOH}(1 \%)$ twice a day during the whole fermentation.

\section{Microarray-Based Comparative Transcriptome Analysis}

For RNA isolation, cells were harvested from 1 litre flask fermentation at $0 \mathrm{~h}$ before the first $\mathrm{MeOH}$ induction and at $24 \mathrm{~h}$ and $48 \mathrm{~h}$ after the first $\mathrm{MeOH}$ induction. About $4 \times 10^{7}$ cells were separated from fermentation broth via centrifuging at $5000 \mathrm{rpm}$ (Biofuge Fresco Heraeus, rotor 3325B) at $4{ }^{\circ} \mathrm{C}$. Cells were then resuspended in $2 \mathrm{ml}$ GITC-containing lysis buffer (RLT buffer from RNeasy Mini Kit, Quiagen [17]) and fast frozen in liquid nitrogen. The frozen cells were kept at $-70{ }^{\circ} \mathrm{C}$ for about 1-3 weeks before being shipped on dry ice to Asuragen Inc./ Texas for further analysis.

RNA isolation was done by Asuragen Inc. following the RiboPureTM-Yeast Instruction Manual (http://www.ambion. com/techlib/prot/fm_1926.pdf). Afterwards, microarray analyses were performed using Affymetrix ${ }^{\circledR}$ Yeast Genome 2.0 Gene Chips following the standard protocol (http://www.affymetrix.com/support/technical/manual/expre ssion_manual.affx). With standard processing, $2 \mu \mathrm{g}$ were used for preparation of biotin-labelled targets (cRNA) using modified MessageAmp ${ }^{\mathrm{TM}}$-based protocols (Ambion Inc., Austin, TX). The cRNA yields were quantified by spectrophotometry and the distribution of transcript sizes was assessed using the Agilent Bioanalyzer 2100 capillary electrophoresis system. Labelled cRNA was fragmented in a $0.5 \mu \mathrm{g} / \mu \mathrm{L}$ reaction and used for array hybridization and washing, according to the standard Affymetrix protocol. In brief, labelled cRNA was resuspended in $5 \mathrm{X}$ fragmentation buffer and incubated at $94{ }^{\mathrm{O}} \mathrm{C}$ for 35 minutes then stored on ice. The hybridization cocktail and the fragmented cRNA mixture were heated to $99{ }^{\circ} \mathrm{C}$ for 5 minutes, and incubated at $45{ }^{\circ} \mathrm{C}$ for 5 minutes. After a final spin to collect the samples, hybridization to arrays was carried out at $45^{\circ} \mathrm{C}$ for 16 hours in an Affymetrix Model 640 hybridization oven. Arrays were washed and stained on an Affymetrix FS450 Fluidics station. The arrays were scanned on an Affymetrix GeneChip Scanner 3000 7G. A summary of the image signal data, detection calls, and gene annotations for every gene interrogated on the array was generated using the Affymetrix Statistical Algorithm MAS 5.0 (GCOS v1.3) algorithm, with all arrays scaled to 1500 . The Affymetrix data were reported in a .dtt (data transfer tool) file containing the Affymetrix data and result files.

For statistical analysis, at first null hypothesis was tested with two-way ANOVA (Analysis of Variance) in multiple group comparison. The goal of this test was to filter out genes that have same expression level across all groups. After that, pair-wise comparison was performed for all interactions to identify significant differences. For every transcript in the pair-wise comparison, an average logged fold-change was calculated. For each pair of comparison, two-sample t-test was carried out for every gene and the derived p-values were adjusted for multiple testing and converted to false discovery rate (FDR) applying Benjamin and Hochberg procedure. As significant threshold for the pair-wise comparison, a false discovery rate of 0.05 was chosen.

\section{SDS-PAGE Analysis and Protein Band Evaluation}

The fermentation culture was centrifuged at $5000 \mathrm{rpm}$ (Biofuge Fresco Heraeus, rotor 3325B) for $5 \mathrm{~min}$ at $4{ }^{\circ} \mathrm{C}$. The extracellular protein was treated in denatured buffer at $95{ }^{\circ} \mathrm{C}$ for $5 \mathrm{~min}$ and SDS-PAGE was performed according to protocol of Laemmli [18]. The SDS-PAGE gels were stained with silver for visualization [19] and with Comassie Blue for band size evaluation. The band size analysis was carried out using Quantity one ${ }^{\circledR}$ version 4.6.3 software (Bio-Rad, Hercules, CA.

\section{RESULTS}

To study the cellular response to the expression of recombinant proteins in the host $P$. pastoris, we performed 
microarray-based transcriptome analysis of $P$. pastoris strain SMD1168 (control) and the two recombinant SMD1168 strains overexpressing $\alpha$-amylase (Amy) and interleukin-2 (IL-2). The yeast transcriptional profiles were analyzed $0 \mathrm{~h}$ before the first $\mathrm{MeOH}$ induction and at $24 \mathrm{~h}$ and $48 \mathrm{~h}$ after the first $\mathrm{MeOH}$ induction. For simplicity, the points of time when the yeast cells were harvested are denoted as $0 \mathrm{~h}, 24 \mathrm{~h}$ and $48 \mathrm{~h}$. At the studied fermentation conditions, all strains showed the similar growth curve (data not shown). At $0 \mathrm{~h}$, all yeast strains were in the logarithmic growth phase of which cell optical densities $\mathrm{OD}_{600}$ varied from 15 to 16 . At $24 \mathrm{~h}$ and $48 \mathrm{~h}$, cells were at the stationary phase and showed similar cell optical densities $\mathrm{OD}_{600}$ of about 30 . At the points of time when the cells were harvested for RNA isolation, we also collected the fermentation broth to examine secretion of extracellular protein.

\section{A. Extracellular Protein Secretion in Recombinant Strains}

The extracellular protein secretion in recombinant yeast strains was examined on Acrylamid gel (Fig. 2). The recombinant proteins IL-2 and amylase were not detected at $0 \mathrm{~h}$. The abundances of each recombinant protein (IL-2 and amylase) at $24 \mathrm{~h}$ and $48 \mathrm{~h}$ were quite similar. In addition, analysis of band size using Quantity one ${ }^{\circledR}$ version 4.6.3 software on coomassie stained gel shown that the amylase bands at both $24 \mathrm{~h}$ and $48 \mathrm{~h}$ were about 4 times higher than those of IL-2 bands (data not showed). It can be explained by the fact that the MW of amylase is $55.0 \mathrm{kDa}$, about 4 times higher than that of Interleukin-2 $(14.0 \mathrm{kDa})$. When comparing both band size and molecular weight of Amylase and IL-2, we concluded that, at the studied conditions, the two $P$. pastoris strains overexpressing Amylase and IL-2 showed the same level of recombinant protein expression.

\section{B. Microarray Based-Transcriptome Analysis}

The experiment was carried out in triplicate in which cell samples used for RNA isolation were harvested from three independent fermentations. In total, for three strains studied at three time points of three fermentations, 27 samples were analysed. The hybridisation signals generated for each strain at each time point were calculated as the mean value from three different fermentations. Afterwards, pairwise transcriptomic comparison was carried out according to time variable (one strain at different time points of the fermentation) and strain variable (different strains at one similar time point of the fermentations).

In microarray-based transcriptome analysis, we used Affymetrix GeneChip®Yeast Genome 2.0 Array [20]. This array contains probe sets to detect transcripts from both $S$. cerevisiae and $S$. pombe, the two most commonly studied species of yeast. The array includes probe sets to detect 5,841 genes in S. cerevisiae and 5,031 genes present in S. pombe. Every probe set contains 11 probes. Each probe is an oligonucleotide of $25 \mathrm{bp}$ long, hybridized to the target sequence.

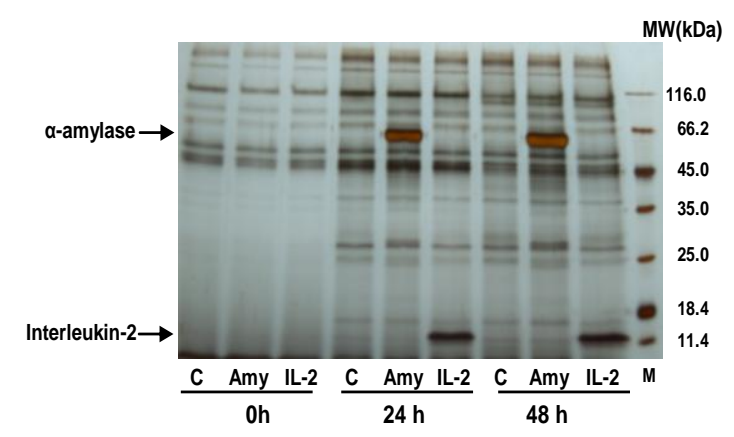

Fig. 2. Analysis of extracellular proteins from recombinant strains produced during fermentation. Crude extracellular protein extracts from culture supernatant of recombinant strains were separated on SDS-PAGE in $12.5 \%$ gels. Protein detection was done by staining with silver nitrate. C: control strain; Amy and IL-2: recombinant strains overexpressing $\alpha$-amylase and interleukin-2, respectively.

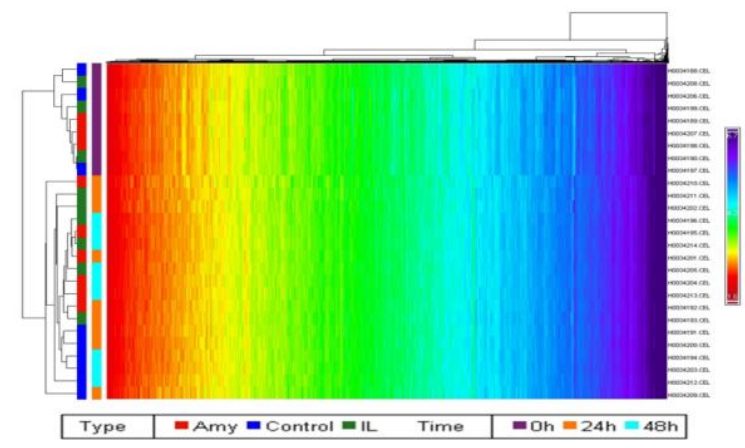

Fig. 3. Heat map of differentially expressed transcripts transcriptome analysis of three studied strains at different time points of fermentations $0 \mathrm{~h}$, $24 \mathrm{~h}$ and $48 \mathrm{~h}$.

The transcriptional analysis of three strains according to time variable showed hundreds of genes differentially expressed in the comparison at $0 \mathrm{~h}$ versus those at $24 \mathrm{~h}$ and $48 \mathrm{~h}$ (TABLE I). In contrast, no significant difference was detected in the transcriptome comparison between $24 \mathrm{~h}$ and $48 \mathrm{~h}$.

To study the cellular mechanism responding to the expression of recombinant proteins, we compare the transcriptional profiles of three studied strains at the several points of time during the fermentation. According to strain variable, only 6 significant differences were identified at the studied time points of $0 \mathrm{~h}, 24 \mathrm{~h}$ and $48 \mathrm{~h}$ (TABLE II). These 6 differences are detected in the comparison between the control strain and either with the IL-2 or Amy strains. No significant difference was detected in the analysis between IL-2 and Amy strains. Among those, it is remarkably that $M F(A L P H A) 1$ gene is up-regulated by more than 15 times at $0 \mathrm{~h}$ in the recombinant strains Amy and IL-2 compared to the control strain. After the first methanol induction, $M F(A L P H A) 1$ transcript about more than 140 times higher in the recombinant strains at both $24 \mathrm{~h}$ and $48 \mathrm{~h}$ comparing to the control strain at the same time points (TABLE II, TABLE III). The difference regarding $M F(A L P H A) 1$ transcript abundance is both identified in comparison regarding time and strain variables of the studied strains.

TABLE I: NUMBER OF SIGNIFICANT DIFFERENCES IDENTIFIED AT TRANSCRIPTIONAL LEVEL OF THE STUDIED P. PASTORIS STRAINS ACCORDING TO TIME VARIABLE. FOR EACH PAIRWISE COMPARISON, THE NUMBER OF SIGNIFICANT DIFFERENTIALLY EXPRESSED GENES WAS CONSIDERED WITH A FALSE DISCOVERY RATE OF 0.05 . 


\begin{tabular}{|c|c|c|c|c|c|c|c|c|c|}
\hline \multirow{2}{*}{$\begin{array}{l}\text { No of significant } \\
\text { differences } \\
\text { (Time) }\end{array}$} & \multicolumn{3}{|c|}{ Control } & \multicolumn{3}{|c|}{ Amy } & \multicolumn{3}{|c|}{ IL-2 } \\
\hline & $24 \mathrm{~h} / 0 \mathrm{~h}$ & $48 \mathrm{~h} / 0 \mathrm{~h}$ & $48 \mathrm{~h} / 24 \mathrm{~h}$ & $24 \mathrm{~h} / 0 \mathrm{~h}$ & $48 \mathrm{~h} / 0 \mathrm{~h}$ & $48 \mathrm{~h} / 24 \mathrm{~h}$ & $24 \mathrm{~h} / 0 \mathrm{~h}$ & $48 \mathrm{~h} / 0 \mathrm{~h}$ & $48 h / 24 h$ \\
\hline Total & 433 & 351 & 0 & 645 & 447 & 0 & 542 & 435 & 0 \\
\hline Increased & 211 & 170 & & 282 & 210 & & 273 & 200 & \\
\hline Decreased & 222 & 181 & & 363 & 237 & & 269 & 235 & \\
\hline
\end{tabular}

TABLE II: SIGNIFICANT DIFFERENCES IDENTIFIED AT TRANSCRIPTIONAL LEVEL OF THE STUDIED STRAINS ACCORDING TO STRAIN VARIABLE. FOR EACH PAIRWISE COMPARISON, THE NUMBER OF SIGNIFICANTLY DIFFERENTIALLY EXPRESSED GENES WAS CONSIDERED WITH A FALSE DISCOVERY RATE OF 0.05. GREY-MARKED SHEETS INDICATE SIGNIFICANT DIFFERENCES IDENTIFIED IN A PAIRWISE COMPARISON ACCORDING TO VARIABLE OF STRAIN.

\begin{tabular}{|c|c|c|c|c|c|c|c|c|c|c|}
\hline \multirow{3}{*}{ Gene } & \multirow{3}{*}{ Probe ID } & \multicolumn{9}{|c|}{ Hybridization ratios } \\
\hline & & \multicolumn{3}{|c|}{$\mathbf{O} \mathbf{h}$} & \multicolumn{3}{|c|}{$24 \mathrm{~h}$} & \multicolumn{3}{|c|}{$48 \mathrm{~h}$} \\
\hline & & $\begin{array}{l}\text { Amy/ } \\
\text { Control }\end{array}$ & $\begin{array}{c}\text { IL-2/ } \\
\text { Control }\end{array}$ & $\begin{array}{l}\text { Amy/ } \\
\text { IL-2 }\end{array}$ & $\begin{array}{l}\text { Amy/ } \\
\text { Control }\end{array}$ & $\begin{array}{c}\text { IL-2/ } \\
\text { Control }\end{array}$ & $\begin{array}{l}\text { Amy/ } \\
\text { IL-2 }\end{array}$ & $\begin{array}{l}\text { Amy/ } \\
\text { control }\end{array}$ & $\begin{array}{c}\text { IL-2/ } \\
\text { Control }\end{array}$ & $\begin{array}{l}\text { Amy/ } \\
\text { IL-2 }\end{array}$ \\
\hline$M F(A L P H A) 1$ & 1775057_at & 15.6 & 19.3 & 0.8 & 146.6 & 153.4 & 1 & 159.0 & 161.0 & 1.0 \\
\hline Bla & $\begin{array}{l}\text { RPTR-Sc-J002682- } \\
\text { 2_s_at }\end{array}$ & 24.8 & 39.7 & 0.6 & 20.0 & 20.0 & 1.0 & 15.2 & 19.1 & 0.8 \\
\hline rpl1001 & 1769984_at & 1.3 & 1.6 & 0.8 & 5.0 & 4.3 & 1.2 & 3.5 & 3.8 & 0.9 \\
\hline$G A L 2$ & 1773096_at & 0.8 & 0.9 & 0.8 & 0.9 & 0.9 & 1.0 & 1.0 & 1.0 & 1.1 \\
\hline$R P B 2$ & 1772025_at & 1.4 & 1.0 & 1.4 & 0.9 & 0.9 & 1.1 & 0.9 & 1.0 & 1.0 \\
\hline PTK2 & 1772327_at & 1.0 & 1.0 & 1.0 & 1.0 & 1.2 & 0.9 & 1.1 & 1.5 & 0.8 \\
\hline \multicolumn{11}{|c|}{$\begin{array}{l}\text { *) Note: } M F(A L P H A) 1 \text { : Mating pheromone alpha-factor, made by alpha cells; interacts with mating type a; Bla: control gene, encoding antibiotics, } \\
\text { produced by some bacteria; Rpl1001: } 60 \mathrm{~S} \text { ribosomal protein L10; GAL2: Galactose permease, required for utilization of galactose; also able to } \\
\text { transport; } R P B 2 \text { : RNA polymerase II second largest subunit B150, PTK2: Putative serine/threonine protein kinase involved in regulation of ion } \\
\text { transport. }\end{array}$} \\
\hline \multicolumn{11}{|c|}{$\begin{array}{l}\text { ABLE III: AVERAGE HYBRIDIZATION SIGNALS OF } 6 \text { SIGNIFICANT DIFFERENCES IDENTIFIED IN THE TRANSCRIPTIONAL ANALYSIS ACCORDING TO STRA } \\
\text { VARIABLE. ANNOTATION FOR GENES AND RELEVANT PROTEINS IS SHOWN IN TABLE } 2 \text {. THE SIGNALS OF EACH GENE WERE CALCULATED AS THE MEAN } \\
\text { VALUE FROM THREE INDEPENDENT HYBRIDIZATIONS. }\end{array}$} \\
\hline Gene & Probeset ID & $\begin{array}{r}\text { Mean } \\
\text { Control } \\
\mathbf{0 ~ h}\end{array}$ & $\begin{array}{r}\text { Mean } \\
\text { Control } \\
\mathbf{2 4 h} \\
\end{array}$ & $\begin{array}{r}\text { Mean } \\
\text { Control } \\
48 \text { h }\end{array}$ & $\begin{array}{r}\text { Mean } \\
\text { Amy } \\
0 \text { h } \\
\end{array}$ & $\begin{array}{r}\text { Mean } \\
\text { Amy } \\
24 \text { h } \\
\end{array}$ & $\begin{array}{r}\text { Mean } \\
\text { Amy } \\
48 \text { h } \\
\end{array}$ & $\begin{array}{r}\text { Mean } \\
\text { IL-2 } \\
0 \text { h } \\
\end{array}$ & $\begin{array}{r}\text { Mean } \\
\text { IL-2 } \\
24 \text { h } \\
\end{array}$ & $\begin{array}{r}\text { Mean } \\
\text { IL-2 } \\
48 \text { h } \\
\end{array}$ \\
\hline$M F(A L P H A) 1$ & 1775057_at & 76.1 & 98.6 & 84.4 & 1187.2 & 14453.2 & 13419.1 & 1471.9 & 15118.2 & 13584.7 \\
\hline Bla & $\begin{array}{l}\text { RPTR-Sc-AJ002682- } \\
\text { 2_s_at }\end{array}$ & 37.5 & 25.3 & 35.4 & 929.4 & 505.5 & 539.8 & 1486.2 & 500.0 & 677.0 \\
\hline rpl1001 & 1769984_at & 652.6 & 249.4 & 324.7 & 847.0 & 1254.6 & 1126.8 & 1054.4 & 1073.6 & 1240.7 \\
\hline$G A L 2$ & 1773096_at & 111.2 & 117.4 & 110.4 & 83.9 & 104.4 & 114.9 & 102.7 & 107.0 & 104.7 \\
\hline$R P B 2$ & 1772025_at & 14.7 & 13.5 & 13.9 & 21.0 & 12.5 & 13.1 & 15.3 & 11.9 & 13.4 \\
\hline PTK2 & 1772327_at & 7.6 & 7.2 & 6.1 & 7.9 & 7.6 & 7.0 & 7.5 & 8.3 & 8.9 \\
\hline
\end{tabular}

TABLE IV: DNA SEQUENCE COMPARISON OF SEQUENCES ENCODING 60 RIBOSOMAL PROTEINS OF S. CEREVISIAE AND S. POMBE VERSUS THAT OF P. PASTORIS GS115 AND DSMZ 70382. IN S. POMBE, THE SEQUENCE IS DENOTED UNDER LOWERCASE LETTER WHILE IN S. CEREVISIAE AND P. PASTORIS, THE GENES ARE NAMED IN CAPITAL LETTERS.

\begin{tabular}{llcc}
\hline YEAST_2 probe sets & \multicolumn{1}{c}{ Probet set target sequence } & \multicolumn{2}{c}{ Similarity to P. pastoris RPL10 sequences } \\
& & GS115 & DSMZ 70382 \\
\hline 1769984_AT & rpl1001, encoding 60S ribosomal protein L10 from S .pombe & $69 \%$ & $69 \%$ \\
\hline 1775248_S_AT & rpl1001, encoding S. pombe 60S ribosomal protein L10 & $69 \%$ \\
\hline rpl1002, encoding S. pombe 60S ribosomal protein L10 & $69 \%$ \\
\hline 1773845_AT & rpl1002, encoding S. pombe 60S ribosomal protein L10 & $65 \%$ \\
\hline
\end{tabular}




\section{DISCUSSION}

The changes in transcriptional profiles of yeast strains at different cellular states have been previously reported in various studies [21], [22]. In our experiment, the identified significant differences according to time variable are absolutely consistent to the physiology of the studied yeast strains. Concretely, at $0 \mathrm{~h}$, the studied strains were at exponentially growth while at $24 \mathrm{~h}$ and $48 \mathrm{~h}$; they were already in stationary phase. Due to that fact, the transcriptional profiles of all studied yeast strains at $0 \mathrm{~h}$ are very much different from those at $24 \mathrm{~h}$ and $48 \mathrm{~h}$ while no change between $24 \mathrm{~h}$ and $48 \mathrm{~h}$ was detected. In addition to reason of cellular state metabolism, it should not be excluded that the methanol induction to studied yeast strains after $0 \mathrm{~h}$ is a factor responsible for differential transcriptional expression. As the yeast cells were induced with methanol at $0 \mathrm{~h}$, the sequences under $A O X 1$ promoter including alpha secretion signal, recombinant genes and native $A O X 1$ genes were overexpressed, contributing to the transcriptional differences between $0 \mathrm{~h}$ versus $24 \mathrm{~h}$ and $48 \mathrm{~h}$.

As our goal in this study is to investigate the cellular response to the expression of recombinant proteins, our analysis does focus on the transcriptional changes at cellular states but rather on the changes occurring among three studied strains at the same points of time.

In the paiwise comparison according to strain variable, the expression of GAL2 and $R P B 2$ genes are showed to be slightly dissimilar in the control and Amy strains at $0 \mathrm{~h}$ (TABLE II). The fold-change of difference was not high and at this time point, expression of recombinant amylase has not yet been induced. We therefore assumed that these differences regarding GAL2 and $R P B 2$ genes may not be really related recombinant protein expression.

In our analysis, it was showed that expression of rpl10 gene encoding for $60 \mathrm{~S}$ ribosomal protein L10 was not much different at $0 \mathrm{~h}$ in all three studied strains (TABLE II). However, at $24 \mathrm{~h}$ and $48 \mathrm{~h}$, this gene was up regulated more than 3.5 times in strain IL-2 and Amy. Theoretically, this result can be explained that as transcription of recombinant genes is regulated under the $A O X 1$ promoter, thus, after the $1^{\text {st }}$ methanol induction, recombinant genes was overexpressed and recombinant proteins were accumulated. This in turn might result in the overexpression of ribosomal protein for extracellular transportation. Nevertheless, by the time when our array experiment was completed, the genome of P. pastoris strains GS115 and DSMZ 70382 have been sequenced and published [13]-[15]. We therefore referred to these two genome databases to further study the difference regarding rpl10 gene expression. The reference of $P$. pastoris genome database has led to the unexpected conclusion on our result.

$S$. cerevisiae and $S$. pombe respectively contain 1 and 3 genes encoding ribosomal proteins (TABLE IV). The Yeas_2 array contains 4 different probe sets to detect these 4 genes. Among those 4 probe sets, only the probe set 1769984_AT (specific for rpl10 gene in S. pombe) resulted in different hybridization signals in microarray-based transcriptome comparison according to strain variable while other probe sets did not. It is showed that the sequences of RPL1O in P. pastoris GS115 and DSMZ 70382 strains are $97 \%$ identical. However, the blast of all probes of
1769984_AT probe set against genomes of $P$. pastoris strains GS115 and DSMZ 70382 revealed that these probes have low similarity not only with RPL10 but also with other ORFs. In other words, the probe set 1769984_AT was not specific enough for studying $P$. pastoris transcriptional expression. The obtained difference regarding this probe set may result from unspecific and/or cross-hybridization of the probes to other transcripts of studied $P$. pastoris strains.

Similarly, profound analysis on PTK2 sequence of $P$. pastoris also revealed that the significant difference regarding $P T K 2$ gene was not reliable (data not showed). $P T K 2$ sequence from $P$. pastoris was much different from those from S. cerevisiae and S. pombe (only about $45 \%$ identical). Our blast also revealed that the relevant probe sets used to detect PTK2 from S.cerevisiae and S.pombe was also not specific for studying P.pastoris transcriptional expression. In addition, the hybridization signal generating from 1772327_at probe set responsible for PTK2 sequence is very low (TABLE III), suggesting that the difference detected by this probe set was due to noise from background signal.

The abundance of $M F(A L P H A) 1$ transcript has been identified as a notable significant difference in transcriptome analysis of studied strains. In fact, the reference of native $P$. pastoris genomes showed that there is no $M F(A L P H A) 1$ in this host. Nevertheless, the genomes of the studied recombinant $P$.pastoris strains contain a part of the $M F(A L P H A) 1$ (270 bps) from S. cerevisiae which was introduced into the integration cassette to serve as the $\alpha$-factor secretion signal (Fig. 1). As this part is originated from $S$. cerevisiae, the relevant probe set from Yeast_2 array is specific for the detection of this part of $M F(A L P H A) 1$ gene in the studied $P$.pastoris strains. The $\alpha$-factor secretion signal and the recombinant gene are under the same $A O X I$ promoter (Fig. 1). However, in the control strain where there is no recombinant gene, the expression of $\alpha$-factor secretion signal was not changed after $\mathrm{MeOH}$ induction (TABLE III). In contrast, in the $P$. pastoris strains overexpressing amylase and IL-2, the $\alpha$-factor secretion signal was already increased by more than 15 times at $0 \mathrm{~h}$ comparing to control strain, suggesting that transcription of recombinant genes and $\alpha$-factor secretion signal was already initiated before $\mathrm{MeOH}$ induction. After $\mathrm{MeOH}$ induction, the expression of this $\alpha$-factor secretion signal is further increased at high level about 140 times in the recombinant strains comparing to control strain (TABLE III). The expression level of $M F(A L P H A 1) / a l p h a$ secretion signal seems to be affected by the expression of recombinant genes amylase and interleukin-2. It is assumed that alpha secretion signal was synthesized in the control strain at lower level as this strain did not have the demand for protein secretion as the two recombinant strains. Another hypothesis is $\alpha$-factor secretion signal was transcribed at the same level in the all studied strains. However, in the control strain, the $\alpha$-factor secretion signal was degraded as the control cells do not need this signal for protein secretion.

Bla gene encoding for beta-lactamase is a control gene from bacteria and not present in the native host $P$. pastoris strains. However, the bla gene is in fact the Amp gene in the integration cassette of our three recombinant $P$. pastoris strains. Amp/bla gene is not designed to be regulated by $A O X 1$ promoter. The microarray analysis showed that compared to the control strain, bla gene is about more than 15 
times up-regulated in Amy and IL-2 strains at all studied points of time $0 \mathrm{~h}, 24 \mathrm{~h}$ and $48 \mathrm{~h}$ (TABLE II, TABLE III). We so far have no suitable explanation for this result.

\section{CONCLUSIONS}

The microarray analysis of P.pastoris strains overexpressing recombinant protein interleukin-2 and amylase via the use of Yeast_2 array revealed some significant differences relevant to expression of alpha secretion signal and marker gene bla gene. No cellular response relevant to expression of native genes from $P$. pastoris was detected in the pairwise transcriptional comparison regarding strain variable.

The profound analysis on some identified significant differences using recently $P$. pastoris genome sequence has also revealed that some identified significant different in fact was not reliable as the probe sets designing to detect $S$. cerevisiae and $S$. pombe from the Yeast_2 array used for this experiment was not specific enough to detect the relevant $P$. patoris genes. Regarding this fact, it could not be ensured that the transcriptional profile studied P.pastoris yeast strains really showed no other significant differences besides $\alpha$-factor secretion and bla gene. In our experiment, it can happen the case that, the integration of the studied recombinant genes indeed results in up/down regulation of certain genes. Nevertheless, these significant differences were not reflected via the probet sets of Yeast_2 array. To have a comprehensive understanding on the cellular response to the expression of recombinant genes in host $P$. pastoris, a specific array is required. The results also stress that precaution should be taken when we evaluate transcriptional data using non-specific microarray.

\section{REFERENCES}

[1] J. L. Cereghino and J. M Cregg, "Heterologous protein expression in the methylotrophic yeast Pichia pastoris," FEMS Microbiol Rev, 24 2000, pp. 45-66.

[2] J. M. Cregg, J. L. Cereghino, J. Shi, and D. R. Higgins, "Recombinant protein expression in Pichia pastoris," Mol Biotechnol, 16, 2000, pp. 23-52.

[3] S. W. Chang, G. C. Lee, and J. F. Shaw, "Codon optimization of Candida rugosa lip1 gene for improving expression in Pichia pastoris and biochemical characterization of the purified recombinant LIP1 lipase," J Agric Food Chem, 54, 2006, pp. 815-822.

[4] L. M. Damasceno, K. A. Anderson, G. Ritter, J. M. Cregg, L. J. Old, and C. A. Batt, "Cooverexpression of chaperones for enhanced secretion of a single-chain antibody fragment in Pichia pastoris," Appl Microbiol Biotechnol, 74, 2007, pp. 381-389.

[5] W. Zhang, H. L. Zhao, C. Xue, X. H. Xiong, X. Q. Yao, X. Y. Li, H. P. Chen, and Z. M. Liu, "Enhanced secretion of heterologous proteins in
Pichia pastoris following overexpression of Saccharomyces cerevisiae chaperone proteins," Biotechnol Prog, 22, 2006, pp. 1090-1095.

[6] W. Zhang, M. Inan, and M. M. Meagher, "Rational design and optimization of fed-batch and continuous fermentations," Methods Mol Biol, 389, 2007, pp. 43-64.

[7] C. Gurramkonda, S. Polez, N. Skoko, A. Adnan, T. Gabel, D. Chugh, S. Swaminathan, N. Khanna, S. Tisminetzky, and U. Rinas, "Application of simple fed-batch technique to high-level secretory production of insulin precursor using Pichia pastoris with subsequent purification and conversion to human insulin," Microb, 9, 2010, pp. 31.

[8] H. L. Zhao, C. Xue, Y. Wang, X. Q. Yao, and Z. M. Liu, "Increasing the cell viability and heterologous protein expression of Pichia pastoris mutant deficient in PMR1 gene by culture condition optimization," Appl Microbiol Biotechnol, 81, 2008, pp. 235-241.

[9] M. Sauer, P. Branduardi, B. Gasser, M. Valli, M. Maurer, D. Porro, and D. Mattanovich, "Differential gene expression in recombinant Pichia pastoris analysed by heterologous DNA microarray hybridisation,' Microb Cell Fact, 3, 2004, pp. 17.

[10] B. Gasser, M. Maurer, J. Rautio, M. Sauer, A. Bhattacharyya, M. Saloheimo, M. Penttilä, and D. Mattanovich, "Monitoring of transcriptional regulation in Pichia pastoris under protein production conditions," BMC Genomics, 8, 2007, pp. 179.

[11] A. Graf, B. Gasser, M. Dragosits, M. Sauer, G.G. Leparc, T. Tüchler, D.P. Kreil, and D. Mattanovich, "Novel insights into the unfolded protein response using Pichia pastoris specific DNA microarrays," BMC Genomics, 9, 2008, pp. 390.

[12] B. Gasser, M. Sauer, M. Maurer, G. Stadlmayr, and D. Mattanovich, "Transcriptomics-based identification of novel factors enhancing heterologous protein secretion in yeasts," Appl Environ Microbiol, 73 2007, pp. 6499-6507.

[13] K. De Schutter, Y. C. Lin, P. Tiels, A. Van Hecke, S. Glinka, J. Weber-Lehmann, P. Rouze, Y. Van de Peer, and N. Callewaert, "Genome sequence of the recombinant protein production host Pichia pastoris," Nat Biotechnol, 27, 2009, pp. 561-566.

[14] D. Mattanovich, A. Graf, J. Stadlmann, M. Dragosits, A. Redl, M. Maurer, M. Kleinheinz, M. Sauer, F. Altmann, and B. Gasser, "Genome, secretome and glucose transport highlight unique features of the protein production host Pichia pastoris," Microb Cell Fact, 8, 2009 pp. 29

[15] D. Mattanovich, N. Callewaert, P. Rouze, Y. C. Lin, A. Graf, A. Redl, P. Tiels, B. Gasser, and K. De Schutter, "Open access to sequence: browsing the Pichia pastoris genome," Microb Cell Fact, 8, 2009, pp. 53.

[16] Invitrogen life technologies. Pichia Expression Kit - A Manual of Methods for Expression of Recombinant Proteins in Pichia pastoris.

[17] Quiagen. RNeasy® Mini Handbook, 2010

[18] U. K. Laemmli, "Cleavage of structural proteins during the assembly of the head of bacteriophage T4." Nature, 227, 1970, pp. 680-685.

[19] H. Blum, H. Beier, and H. S. Gross, "Improved silver staining of plant proteins, RNA and DNA in polyacrylamide gels," Electrophoresis, 8, 1987, pp. 93-99.

[20] Affymetrix. GeneChip® Yeast Genome 2.0 Array, 2005.

[21] G. G. Roberts and A. P. Hudson, "Transcriptome profiling of Saccharomyces cerevisiae during a transition from fermentative to glycerol-based respiratory growth reveals extensive metabolic and structural remodeling," Mol Genet Genomics, 276, 2006, pp. 170-186.

[22] T. C. James, S. Campbell, D. Donnelly, and U. Bond, "Transcription profile of brewery yeast under fermentation conditions," $J$ Appl Microbiol, 94, 2003, pp. 432-448. 